\title{
A MAGYAR TANYÁK FUNKCIÓ-VÁLTOZÁSÁNAK ELEMZÉSE
}

\section{Ferencz Árpád - Deák Zsuzsanna}

\begin{abstract}
Absztrakt: Településfejlesztési és vidékfejlesztési szempontból is fontos tényezőként jelenik meg napjainkban a tanyarendszer kérdése. Munkánkban a magyar Nagyalföld Duna-Tisza közén a legjelentősebb tanyás területet, a Homokhátságot vizsgáltuk. Az alföldi tanyákat funkciójuk szerint gazdasági, lakó és lakatlan funkçiókra osztottuk, ezek arányát és jellemzőt mutatja be a tanulmányunk. A hagyományos funkcióval rendelkező mezőgazdasági termelésen alapuló tanyák Magyarországon teljes mértékben visszaszorultak. A legfontosabb változások a tisztán lakófunkció térnyerésében, a tanyák hobbitanyává válásában, a vendégfogadás, idegenforgalom megjelenésében jelennek meg, ezekhez társult az elhagyott, üres tanyák nagyszámú megjelenése. A tanyavilág ügye Magyarországon komplexen kezelendő téma, amelyben kormányzati szinten és a célirányos programok kidolgozásával kell megoldani.
\end{abstract}

\begin{abstract}
The issue of the rural small farm system has become an important factor both in city and in rural development. We studied the major small farm area, the sand ridges of the Hungarian Great Plain between the Danube and Tisza rivers. We have divided the farms in the Great Plains based on their purpose into economic, residential and uninhabited functions. The proportion and features of these are presented in this paper. The number of farms with traditional agricultural functions has greatly diminished in Hungary. The main changes that can be seen are the expansion of the purely residential functions, the spreading of hobby-farms and the appearance of farms in the hospitality and tourism business. In addition, a large number of them simply became empty or abandoned. The issue of small rural farms in Hungary is a complex problem which must be solved at the governmental level by developing targeted programs.
\end{abstract}

Kulcsszavak: vidékfejlesztés, magyar tanyák, funkcióváltás

Keywords: rural development, Hungarian farms, change of functionality

\section{Bevezetés}

A klasszikus tanya legáltalánosabb fogalmát Györffy (1937) fogalmazta meg: „Tanya, vagy régebbi nevén szállás alatt a magyar Alföld szétszórt, magányos telepeit értjük melyek ma a mezőgazdasági munkák, s általában a gazdálkodás középpontjai. A tanya azonban nem önálló településforma, hanem a hozzá tartozó földbirtokkal együtt valamely város vagy nagyközség függvénye". Ma az érvényes jogi definíciót a termőföldről szóló 1994. évi $L V$. $t$. 3.\$-a határozza meg, mely szerint „tanya a település külterületén lévő mezőgazdasági tevékenység (növénytermesztés, állattenyésztés, továbbá az ezekkel kapcsolatos termékfeldolgozás és terméktárolás) céljára létesített lakó- és gazdasági épület, épületcsoport és az azonos helyrajzi szám alatt hozzá tartozó, legfeljebb $6000 \mathrm{~m}^{2}$ területü föld együttese". A tanya Magyarországon különösen a nagyalföldön, ahol nem egyszerủen csak települési szórvány, hanem sok évszázados hagyományú, sajátos települési, gazdálkodási és társadalmi létforma egyszerre.

A hagyományos értékrendet képviselő tanyákból fejlődtek ki azok a mára meghatározó jelentőségü idegenforgalmi létesítmények, melyek a település térségfejlesztő szerepét is erősítve hozzájárultak (Beluszky, 2003). A tanyák csoportosítását, jellemzőit korábbi szakirodalmi adatok többféleképpen írták le. 
Erdei Ferenc az 1930-as évek tanyavilágát legföképpen szociológiai szemszögböl jellemezte.

A tanyavilág, mint lakóhely tehát éppen olyan jellegzetes vonásokkal bír, mint a város vagy a falu. A falvak különbözỏek, saját jellegzetességeik vannak, a tájegységek szerint a tanyavilágra is jellemző eltéréseket figyelhetünk meg. Vannak vidékek, ahol a tanyasor terjedt el, ahol egy utcára emlékeztető formát látunk, máshol a tanyabokor a jellemző, ami egy egészen kicsi falunak tünhet, de mindössze csak egy-két házból áll és egy központi tér mindig van köztük (Balogh, 2004).

A csoportos településeket megelőzve a rendszerben elfoglalt helyük szerint beszélhetünk szórvány- és halmaz településekröl. Az alábbiakban felsorolt tanyatípusokat ennek megfelelően rendezve, a szórvány településekhez tartozik a hegyi szállás, a szőlőhegyi tanya mellett az alföldi szórt tanya. A halmazos településekhez sorolhatjuk be a sortanyát, a bokortanyát, a majorságot, illetve a szereket és szegeket, amelyek már átmenetet képeznek a falu és a tanya közt (Körmendy, 2005).

Szórt tanya a legkisebb településtípus, amely az Alföldön a leggyakoribb. A pusztán apró szigetekként helyezkednek el a különálló házak. A távolság lehet köztuik néhány száz méter, akár több kilométer is (Juhász, 2004).

Tanyasorok kétféle megjelenési formája szerit lehetnek látsźólagos tanyasorok, amelyek kialakulása természetföldrajzi okokra vezethető vissza, valódi tanyasorok, amelyeket közigazgatási határozattal alakítottak ki. Legismertebbek a Magyarországon Szarvas városhoz közeli tanyasorok. Itt a tanyaépületek többsége kiépült az utak mellé. A házak kerítettek, zárt utcavonulatot képeznek. Mögöttük hosszú csíkokban húzódnak a szántóföldek. Az utcák eredetileg dűlőutak voltak, és fokozatos beépüléssel nyerték el sorfaluhoz hasonló képüket. Hasonló tanyai utcák alakultak ki Szabadka határában, majd a szabadkai határból kivált Csikéria, Kelebia és Tompa község, amely több kilométernyi hosszúságban kanyargó út menti tanyasorokból áll (Kiss, 2004).

Bokortanyák a tanyák legritkább formái, már Magyarországon csak a Nyírségben fordulnak elő. Általában szlovák ajkú telepített emberek tanyai formációja volt. Idegen területen a biztonság volt a meghatározó, ezért a jobb védekezés szempontjából körívben jelölték ki a birtokokat és ezáltal egy zárt települési formát alakítottak ki (Kovács, 2006).

Az magyar alföldi volt mezövárosok tanyás térségeiben a 80-as évek végén elindul a tanyák urbanizációjának a folyamata. Föleg a volt mezővárosokat övező belsö, volt kertes tanyazónában épültek új tanyák. A tanyaközségekbe is megkezdődött a városokból történő kiköltözés. A városból történő kivándorlással újfajta tanya-város kapcsolat következik be és ezzel egyidejüleg jelennek meg az újfajta funkciók (Csatári, 2004; Csatári et al, 2006). A napjainkra jellemző fejlődési folyamatot elsősorban a nem gazdasági jellegü funkciók erősödése jellemzi (Ehleiter, 2007). 


\section{Anyag és módszer}

A rendszerváltozás nyomán mind a földtulajdonviszonyok, mind a mezőgazdaság üzemszervezeti rendszere alapvetően megváltoztak. Ezeket a jelentős változásokat csak tetézte a globális klímaváltozás következtében érzékelhető eröteljes szárazodás az Alföld markáns tanyás középtáji vidékén, a Duna-Tisza közén. Ezek az alapvető és jelentős kiinduló problémák motiválták ezt a három évig tartó átfogó tanyakutatást, amely Bács-Kiskun, Csongrád és Békés megye településein tárta fel a változó környezet-, területhasználat tanyás térségekre jellemző trendjeit, a mező- és élelmiszergazdaságnak a megmaradt tanyás gazdaságokra vonatkoztatható eltartó képességét, illetve a tanyák társadalmának problémáit, települési konfliktusait. $\mathrm{Az}$ egyedi módszerrel kidolgozott, a külterületek modellezésére alkalmas térinformatikai eljárásokkal, illetve csaknem 6000 tanya egyedi felmérésével, a tanyák és a külterületi lakott helyek tipizálását végezte el a Magyar Tudományos Akadémia Regionális Kutatások Központjának Alföldi Tudományos Intézete. A vizsgálat reprezentativitását tekintve 76\%-os, mert a 104 településböl 96 település szolgáltatott adatot, amelyeket fel lehetett dolgozni, illetve a felmérésben résztvevő közremüködők sem rendelkeztek minden tanya vonatkozásában pontos számszerüsíthető adattal. A nyilvántartott 53709 tanyából 24\%-ra, azaz 13009 tanyára nem volt adat.

A felmérés és program kidolgozás célja a tanyás térségek helyzetének javítására irányult, különös tekintettel a tanyavillamosítási feladatokra, az infrastrukturális hátrányok felszámolására, az ellátási, szociális különbségek lecsökkentésére.

\section{Eredmények és értékelésük}

Magyarországon a Homokhátság tanyáinak átfogó felmérése alapján a következő helyzetkép fogalmazható meg. A vizsgált tanyák funkcióinak megoszlását az 1. ábra szemlélteti.

\subsection{Gazdasági funkciójú tanyák, típusaik szerinti elemzés}

A gazdasági tevékenység megjelenhet önállóan vagy lakófunkcióval együtt. A százalékos adatokból megállapítható, hogy arányaiban a lakófunkcióval rendelkező tanyák mellett a második nagy tömböt a gazdasági funkcióval rendelkezö tanyák teszik ki. Az életképes tanyarendszer egyik meghatározó szegmense. Az a 9607 tanya, amely az összes létezỏ tanyának a $27 \%$-át, illetve az összes müködő tanyáknak a 35\%-át tesz ki további csoportokra bontható a gazdasági tevékenység nagyságának függvényében. Az összefüggést a 2. ábra mutatja be. 


\section{1. ábra: A magyar tanyák funkció megoszlása Magyarországon}

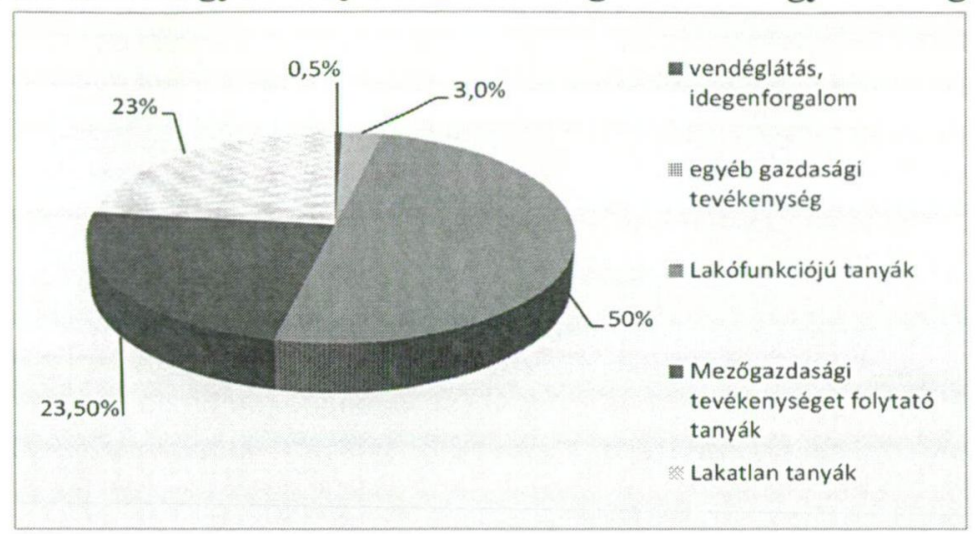

3.2. Gazdasági funkciójú tanyák, típusaik szerinti elemzés

A gazdasági tevékenység megjelenhet önállóan vagy lakófunkcióval együtt. A százalékos adatokból megállapítható, hogy arányaiban a lakófunkcióval rendelkező tanyák mellett a második nagy tömböt a gazdasági funkcióval rendelkező tanyák teszik ki. Az életképes tanyarendszer egyik meghatározó szegmense. Az a 9607 tanya, amely az összes létező tanyának a 27\%-át, illetve az összes müködő tanyáknak a 35\%-át tesz ki további csoportokra bontható a gazdasági tevékenység nagyságának függvényében. Az összefüggést a 2. ábra mutatja be.

\section{2. ábra: A Gazdasági funkciójú tanyák aránya a Homokhátságon}

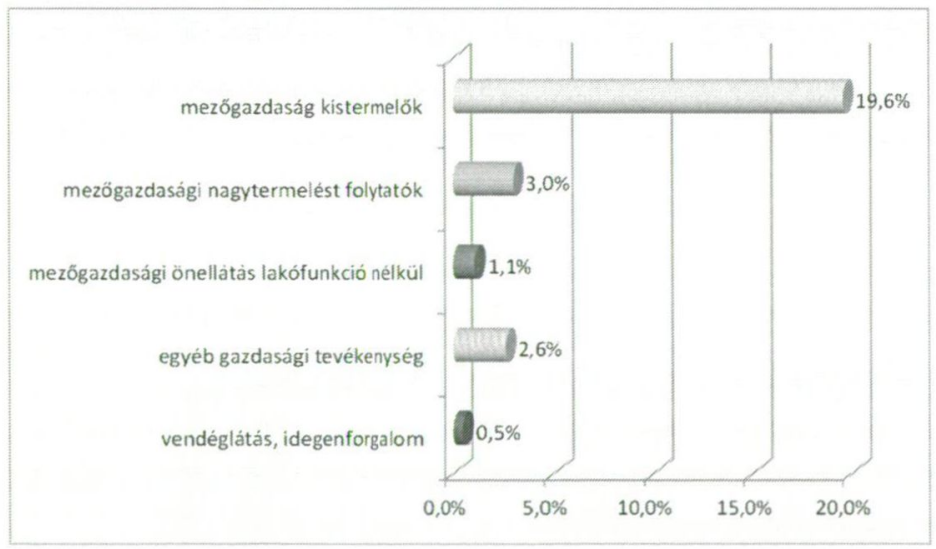

\subsubsection{Mezögazdasági tevékenységet folytató tanyák}

A mezőgazdasági tevékenységet folytató tanyák közt érdemes különbséget tenni aszerint, hogy alapvetően önellátásra rendezkedtek be vagy valódi mezőgazdasági nagytermelést folytató árutermelő vállalkozások színhelyeiről beszélünk. A tanyán zajló mezőgazdasági tevékenységre jellemző, hogy néhány nagygazdán túl, uralkodóan a kistermelők tömegeinek gazdálkodása határozza meg. Az általában 
tapasztalható alacsony fokú gépesítettség, a használt technológia elmaradottsága, a piaci értékesítés nehézségei és a tökeszegénység jellemző a mai Magyarország mezögazdaságára. Amennyiben a hagyományos alföldi tanyarendszer fennmaradását, megőrzését tüzzük ki, mint elérendő célt, akkor figyelemmel kell lenni az Európai Unió mezőgazdaság és vidékfejlesztési politikájára, hiszen elérhetőek azok a támogatások, programok, amelyek segítik megörizni a tradicionális tanyasi biogazdálkodást.

\subsubsection{Egyéb gazdasági tevékenységet folytató tanyák}

Ebbe a kategóriába sorolhatóak be az ipari, kisipari, kereskedelmi, esetleg szolgáltató tevékenységet folytató vállalkozások külterületi telephelyei, valamint azok a tanyák, amiket tulajdonosaik csak telephelyként, de még mindig mezögazdasági termelésükhöz kapcsolódva használnak. Ezt a csoportot is kétirányú folyamat eredményének tekinthetjük. Általában egy régi családi tanya veszíti el lakófunkcióját, mert a tulajdonos inkább beköltözik egy szorosabb közösségbe, és onnan jár ki a munkákat elvégezni. A lakóépület is gazdasági helyiséggé válik a korszerüsítések elmaradásával.

\subsubsection{Vendéglátást, idegenforgalmat folytató tanyák}

A turisztikai tevékenység elterjedésének jelentősége abban áll, hogy a tanyai környezetben új funkciót és munkalehetőségeket teremtettek, illetve olyan infrastrukturális (telefon, internet, müholdvevő, gáz, víz stb.) és szolgáltatási hátteret (szálláshely, étkezés, úszás, lovaglás, masszázs stb.) alakítottak ki, amely az agro-, öko- és lovasturizmus minöségi igényeinek is egyre inkább meg tud felelni. Az agroturizmus a gazdasági tanyák új típusú átrendeződése. Új lehetőséget nyit a tanyák ésszerủ hasznosításának, valamint újabb megélhetőségi lehetőséget biztosít. $\mathrm{Az}$ unióhoz való csatlakozás során illeszkedik a fenntartható vidékfejlesztési programba. Pályázati lehetőségek támogatják a fejlesztését és fenntartását. Ezzel szemben meg kell felelni az Európai Unió által elöírt elvárásoknak, rendelkezésre kell állni különböző csoportok fogadására a gazdaság tevékenységének bemutatására.

\subsection{Lakófunkciójú tanyák, típusaik szerinti elemzés}

A lakófunkciók szerinti vizsgált tanyák száma 17624 volt, ami a teljes felmért tanyák 50\%-át tette ki. A lakófunkciós tanyák típusainak arányát a 3. ábra mutatja be.

\subsubsection{Lakófunkció és mezögazdasági önellátás}

Sokan választották az olcsó lakáskörülmények miatt a kültèrületet kényszerlakóhelyként. A városból kiköltözők sokszor kényszerüségből is, de megelégszenek a külterületek nyújtotta szegényesebb körülményekkel, mert a belterületi infrastruktúra költségeit nem tudják folyamatosan finanszírozni. Az olcsóbb élet lett bizonyos esetekben a külterület telepítö tényezője. Sajnálatosan a szociális problémák is ezekhez a társadalmi csoportokhoz köthetőek. Számukra egyre nehezebbé válik az egészségügyi szolgáltatások elérése vagy az oktatási intézményekbe való eljutás. 
Erre a belső zónára elsődlegesen olyan fiatal családok költöznek ki, akik az elfogadható ingatlanárak mellett vállalják a közeli városba való ingázást. A városi munkahely és a szolgáltatások elérhető közelsége és a saját kertes családi otthon megfelelő otthont biztosít számukra. Itt a mezőgazdasági funkció teljesen háttérbe szorul.

\section{3. ábra: A lakófunkciós tanyák arányainak alakulása Magyarországon}

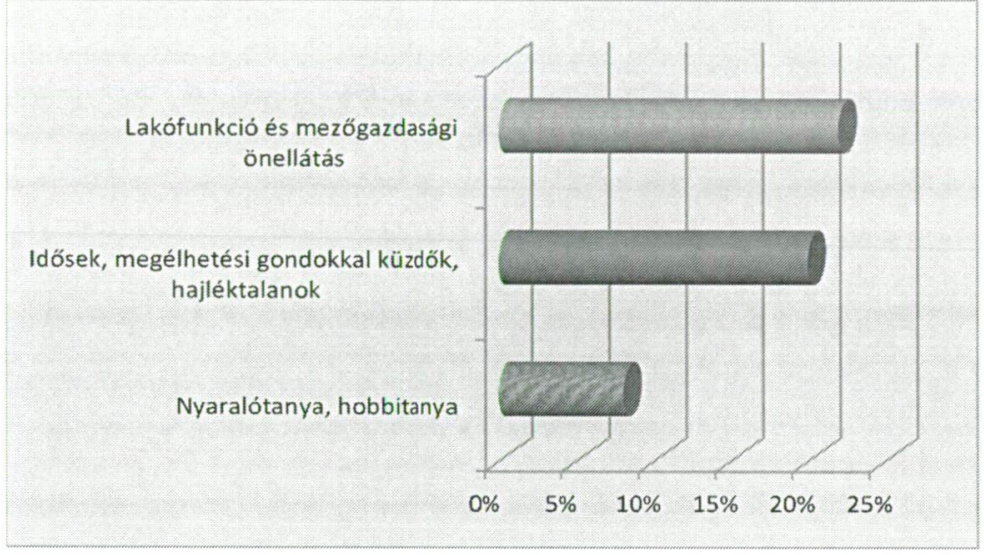

\subsubsection{Idősek, megélhetési gondokkal küzdök}

A tanyák lakói már nyugdíjas korúak, termeléssel már nem tudnak foglalkozni. Csekély nyugdíjukból a felújításokra nem jut és több esetben még az áramot sem vezettették be az épületekbe. A kötődésük azonban erős ahhoz, hogy beköltözzenek a városba. Ebbe a csoportba tartoznak a kevésföldű, vagy földnélküli munkavállaló rétegek, akik a tanyán élést gyakran kényszerhelyzetként élik meg. Ők aktív korú, nem gazdálkodó tanyai lakosok. Elsősorban fiatalokról, kisgyermekes, fiatal családokról van szó, de az idősebbek köréböl is kerülnek ki olyanok, akik elhagynák a tanyát, de az ingatlan értéke miatt nem tudnak elköltözni a tanyáról. A harmadik csoportot a szegények, elesettek képviselik, akiknek a társadalom perifériáján élők meghúzódó helyeivé válnak a még meglévő komforthiányos épületek. A legkérdésesebb ez a csoport, mely a legnagyobb szociális, gazdasági és egészségügyi problémák tömegét vonja maga után.

\subsubsection{Nyaralótanya, Hobbitanya}

A kategóriába tartozó tanyák közül örökölt és megvásárolt ingatlanok egyaránt megtalálhatóak. Többféle funkcióra orientálódtak: saját célú pihenésre, kikapcsolódásra, tanyasi turizmus idegenforgalom céljaira. A saját célú pihenőtanyák egyaránt megtalálhatók hazai és külföldi tulajdonban. Jól megközelíthetők és minden infrastruktúrával ellátottak, minden szociális igényt kielégítenek (fürdőszoba, úszómedence, golf, teniszpálya, lovaglás). Fenntartásukat gondozókra bízzák, így állandó felügyelet alatt vannak. 
A vizsgált tanyák 12\%-a, azaz 4943 db mára megszünt, eltünt. A létezö tanyák közel egynegyede, (23\%-a) 8524 db lakatlan.

\section{Következtetések, összegzés}

A tanyás térségek fenntarthatósági esélye romlott, környezeti státuszát jellemző mutatói negatív irányba mozdultak el. A felzárkózást alapjában nehezítő centrumoktól való távolság és rossz elérhetőség, a gazdasági vérkeringésből kimaradó szórványtelepülések egyre nehezebb körülmények közé kerültek. A DunaTisza közén az 1990-es évektöl felerösödve igen összetett konfliktushelyzet alakult ki. Mivel számos jel mutat arra, hogy a társadalmi-gazdasági folyamatok nem segítik elő az alföldi, vidéki területek fejlettebb térségekhez történő felzárkózását, a meglévő regionális különbségek csak konzerválódnak. Ha tovább folytatódik a társadalmi-gazdasági-környezeti leszakadás, azzal a tanyás területek elveszíthetik népességüket, borúlátóbb vélekedések szerint pedig hazánk térképéröl is eltünhetnek a tanyák a XXI. század közepére. A tanyás térségek problémái nem szükíthetők le egyetlen problémára, például a villany nélküli tanyákra, a rossz külterületi utakra vagy a mezőgazdaság jövedelmezőségi problémáira, hanem rendkívül sokfélék, környezeti, szociális, kulturális, közösségi és gazdasági aspektusokkal. Ennek megfelelően megoldásuk is átfogó fejlesztési program keretében lehetséges, hiszen az egyes problémák között összefüggések mutatkoznak.

\section{Köszönetnyilvánítás}

Köszönettel tartozunk a kutatás támogatásáért, amely az EFOP-3.6.1-16-201600006,,A kutatási potenciál fejlesztése és bővítése a Pallasz Athéné Egyetemen" pályázat keretében valósult meg. A projekt a Magyar Állam és az Európai Unió támogatásával, az Európai Szociális Alap társfinanszírozásával, a Széchenyi 2020 program keretében valósul meg.

\section{Irodalomjegyzék}

A termöföldröl szóló 1994. évi LV. törvény 3.\$

Balogh L. (2004): Bács-Kiskun megye tanyás térségeinek múltja, jelene és jövője. In: Csatári B., Kiss A. (szerk.): Tanyai Kaleidoszkóp. MTA RKK Alföldi Tudományos Intézete, Kecskemét.

Beluszky P. (2003): Magyarország településföldrajza, Dialóg Campus Kiadó, Budapest-Pécs.

Csatári B. - Kanalas I. (2006): A progresszió fogalmának értelmezése a Homokhátság tanyás térségeiben. A FALU, 21 (2): 98.

Csatári B. (2004) Tanyai átalakulás az elmúlt 50 évben. In: Csatári B., Kiss A. (szerk.): Tanyai Kaleidoszkóp. MTA RKK Alföldi Tudományos Intézete, Kecskemét.

Ehleiter J. (2007) Urbanisztika és Regionalitás (Közigazgatási urbanisztika I). HVG ORAC, Budapest.

Erdei F. (1942): Magyar tanyák. Akadémia Kiadó, Budapest.

Györffy I. (1937) A magyar tanya. Földrajzi közlemények 62 (4-5): 70-93.

Juhász A. (2004) A tanyák múltja - kialakulásuktól az elterjedésükig. In: Csatári B., Kiss A. (szerk.):

Tanyai Kaleidoszkóp. MTA RKK Alföldi Tudományos Intézete, Kecskemét.

Kiss A. (2004) Hogyan tovább tanyavilág? In: Csatári B., Kiss A. (szerk.): Tanyai Kaleidoszkóp. MTA RKK Alföldi Tudományos Intézete, Kecskemét.

Kovács A. (2006): A tanyás térségek környezeti alapproblémája. A FALU. 22 (2): 57. 
276• Ferencz A. - Deák Zs.

Körmendy I. (2005): Haldokló falvak. ÖN-KOR-KÉP 10 (3): 18. 